\title{
Pengaruh N-Gram terhadap Klasifikasi Buku menggunakan Ekstraksi dan Seleksi Fitur pada Multinomial Naïve Bayes
}

\author{
Esti Mulyani*, Fachrul Pralienka Bani Muhamad, Kurnia Adi Cahyanto \\ Program Studi Teknik Informatika, Politeknik Negeri Indramayu, Indramayu, Indonesia \\ Email: estimulyani@polindra.ac.id
}

\begin{abstract}
Abstrak-Perpustakaan memiliki tugas utama dalam proses pengolahan bahan pustaka yaitu melakukan klasifikasi buku menurut cara-cara tertentu. Dewey Decimal Classification (DDC) merupakan metode yang paling banyak digunakan di dunia untuk menentukan klasifikasi buku (labelling) pada perpustakaan. Keunggulan metode DDC ini yaitu bersifat universal dan lebih sistematis. Namun metode ini kurang efisien mengingat banyaknya jumlah buku yang harus di klasifikasi pada sebuah perpustakaan, serta pelabelan yang harus diperbarui mengikuti perbaruan label pada DDC. Sistem klasifikasi otomatis akan menjadi solusi yang tepat untuk permasalahan ini. Klasifikasi otomatis dapat dilakukan dengan menerapkan metode text mining. Pada penelitian ini pemrosesan kata dalam judul buku dilakukan dengan N-Gram (Unigram, Bigram, Trigram) sebagai pembangkitan fitur. Fitur yang telah dibangkitkan kemudian dilakukan seleksi fitur. Proses klasifikasi judul buku dilakukan dengan menggunakan algoritma Multinomial Nä̈ve Bayes. Penelitian ini menguji pengaruh Unigram, Bigram, Trigram pada klasifikasi judul buku dengan menggunakan ekstraksi fitur dan seleksi fitur pada algoritma Multinomial Nä̈ve Bayes. Hasil akurasi klasifikasi menunjukan Unigram memiliki akurasi tertinggi sebesar 74,4\%
\end{abstract}

Kata Kunci: Ekstraksi Fitur; Klasifikasi; Seleksi Fitur; Multinomial Nä̈ve Bayes; N-Gram

Abstract-Libraries have the main task in the processing of library materials by classifying books according to certain ways. Dewey Decimal Classification (DDC) is the method most commonly used in the world to determine book classification (labeling) in libraries. The advantages of this DDC method are universal and more systematic. However, this method is less efficient considering the large number of books that must be classified in a library, as well as labeling that must follow label updates on the DDC. An automatic classification system will be the perfect solution to this problem. Automatic classification can be done by applying the text mining method. In this study, searching for words in the book title was carried out with $\mathrm{N}$ Gram (Unigram, Bigram, Trigram) as a feature generation. The features that have been raised are then selected for features. The process of book title classification is carried out using the Naïve Bayes Multinomial algorithm. This study examines the effect of Unigram, Bigram, Trigram on the classification of book titles using the feature extraction and selection feature on Multinomial Naïve Bayes algorithm. The test results show Unigram has the highest accuracy value of $74.4 \%$.

Keywords: Classification; Feature Ekstraction; Feature Selection; Multinomial Naïve Bayes; N-Gram

\section{PENDAHULUAN}

Perpustakaan merupakan salah satu bentuk organisasi sumber belajar yang terdiri atas suatu proses perencanaan, pengorganisasian, pergerakan dan pengawasan dalam suatu unit kerja untuk mengumpulkan, menyimpan, dan memelihara koleksi bahan pustaka yang dikelola dan diatur secara sistematis dengan cara tertentu dengan memanfaatkan sumber daya manusia untuk dimanfaatkan sebagai sumber informasi [1].

Perpustakaan memiliki tugas utama dalam proses pengolahan bahan pustaka yaitu melakukan klasifikasi buku menurut cara-cara tertentu. Dewey Decimal Classification (DDC) merupakan metode yang paling banyak digunakan di dunia untuk menentukan klasifikasi buku (labelling) pada perpustakaan. Keunggulan metode DDC ini yaitu bersifat universal dan lebih sistematis [2]. DDC adalah klasifikasi sistem hirarki yang menganut prinsip "decimal" untuk membagi semua bidang ilmu pengetahuan ke dalam 10 (sepuluh) kelas utama. 10 (sepuluh) kelas utama tersebut diberi kode/lambang angka (selanjutnya disebut notasi). Dalam DDC ini semakin khusus suatu subyek buku, maka semakin panjang notasinya. Karena banyak angka yang ditambahkan pada notasi dasarnya. Pembagian notasinya berdasarkan ketagori umum ke khusus. Kegiatan klasifikasi buku dengan metode DDC ini memerlukan usaha yang besar, pustakawan harus melewati beberapa tahap untuk dapat menentukan klasifikasi buku. Tahap pertama pustakawan dapat melakukan klasifikasi dengan melihat informasi pada katalog buku. Namun tidak semua buku memiliki informasi yang lengkap pada katalog buku. Jika informasi katalog buku tidak lengkap, maka tahap kedua pustakawan dapat melakukan klasifikasi dengan melihat judul buku. Namun jika judul buku terlalu umum maka tahap ketiga pustakawan dapat melakukan klasifikasi buku dengan melihat synopsis buku dan menganalisanya. Dari proses analisa tersebut barulah diperoleh hasil klasifikasi buku berdasarkan metode DDC. Hal ini kurang efisien mengingat banyaknya jumlah buku yang harus di klasifikasi pada sebuah perpustakaan, serta pelabelan yang harus diperbarui mengikuti perbaruan label pada DDC. Sistem klasifikasi otomatis akan menjadi solusi yang tepat untuk permasalahan ini.

Klasifikasi otomatis dapat dilakukan dengan menerapkan metode text mining. Penelitian tentang klasifikasi dengan metode text mining telah banyak dilakukan oleh peneliti sebelumnya, diantaranya: Penelitian yang berfokus pada otomatisasi klasifikasi tugas akhir menggunakan deskripsi singkat dibandingkan antara dua algoritma, K-Nearest Neighbor ( $K$-NN) dan Nä̈ve Bayes Classifier, sehingga Nä̈ve Bayes Classifier memiliki akurasi tertinggi $(65,4 \%)$ dibandingkan dengan K-NN $(51,14 \%)$ [3]. Nä̈ve Bayes Classifier merupakan algoritma yang memiliki metode yang lebih banyak digunakan karena kesederhanaan dan efektivitas komputasi [4]. Dalam penelitian lain diketahui bahwa algoritma Multinomial Nä̈ve Bayes memiliki kinerja sedikit lebih baik dari 
algoritma Nä̈ve Bayes Classifier [5], karena Multinomial Nä̈ve Bayes menggunakan distribusi multinomial untuk masing-masing fitur. Peningkatan kinerja yang lebih baik untuk Multinomial Nä̈ve Bayes dapat dilakukan dengan menerapkan seleksi fitur pada tahap preprocessing. Hal ini dilakukan untuk mengatasai permasalahan pada pengklasifikasi standar Nä̈ve Bayes yaitu ketika fitur (jumlah kata dalam dokumen, atau judul buku) dalam sebuah dokumen terlalu banyak hasil perhitungan akan terlalu kecil sehingga tidak bisa diwakili oleh variabel pemrograman floating point standar tipe data seperti float atau double. Dalam penelitian ini diusulkan penerapan metode ekstraksi fitur CountVectorizer dan TF-IDF. Selain itu diterapkan juga seleksi fitur Information Gain dan metode pengolah predictive text $\mathrm{N}$-Gram.

Ekstraksi fitur adalah salah satu teknik penting dalam reduksi data untuk menemukan fitur yang paling penting [6]. Khadim, pada penelitiannya membandingkan dua metode pembobotan untuk ekstraksi fitur yaitu BM25 dan TF-IDF [7]. Pada penelitian tersebut digunakan dua metode berbeda (BM25 dan TF-IDF) untuk melakukan ekstraksi kata kunci dari data postingan twitter yang telah dikumpulkan. BM25 digunakan untuk menentukan peringkat kumpulan dokumen tanpa informasi terkait. Sedangkan TF-IDF digunakan untuk melakukan pembobotan fitur berdasarkan frekuensi pada masing-masing istilah yang terkait dengan istilah lain dalam kelas yang berbeda. Hasil penelitian tersebut di peroleh kesimpulan bahwa penerapan metode TF-IDF lebih unggul dibandingkan dengan metode BM25. Hal ini ditunjukan dengan perolehan nilai maksimum F1-measure sebesar 89.77 untuk TF-IDF dan 89.16 untuk BM25. Selanjutnya seleksi fitur juga penting untuk dilakukan, karena masalah utama klasifikasi teks adalah banyaknya fitur. Sebagian besar fitur adalah noise yang tidak relevan yang dapat menyesatkan pengklasifikasi. Oleh karena itu, pemilihan fitur sering digunakan dalam klasifikasi teks untuk mengurangi dimensi ruang fitur dan meningkatkan performa. Information Gain (IG) adalah salah satu algoritma pemilihan fitur yang paling efektif, mudah dan memiliki kemampuan identifikasi jenis teks yang kuat [8].

Sedangkan N-Gram merupakan salah satu model yang tepat dalam pengelolahan data berupa teks di data mining dan pemrosesan kata [9] untuk membangkitkan fitur. N-Gram dapat digunakan untuk membangkitkan karakter dan kata serta memprediksi kata berikutnya dalam urutan kata tertentu. Dalam pembangkitan karakter, $\mathrm{N}$-Gram terdiri dari substring sepanjang n karakter dari sebuah string. Pada penelitian yang dilakukan oleh Xinwei et all, menunjukan hasil bahwa N-Gram dapat meningkatkan kinerja klasifikasi dengan pengujian precision, recall, dan F1-Score [10]. Berdasarkan hasil uraian tersebut, pada penelitian ini akan diuji pengaruh N-Gram terhadap klasifikasi buku menggunakan ekstraksi fitur, seleksi fitur pada algoritma Multinomial Nä̈ve Bayes.

\section{METODOLOGI PENELITIAN}

\subsection{Metodologi Penelitian}

Metode yang diusulkan pada penelitian ini yaitu penerapan metode ekstraksi fitur CountVectorizer dan TF-IDF. Selain itu diterapkan juga seleksi fitur Information Gain (IG) dan metode pengolah predictive text $\mathrm{N}$-Gram. Metode ekstraksi fitur dan seleksi fitur tersebut di terapkan pada algoritma klasifikasi Multinomial Naïve Bayes.

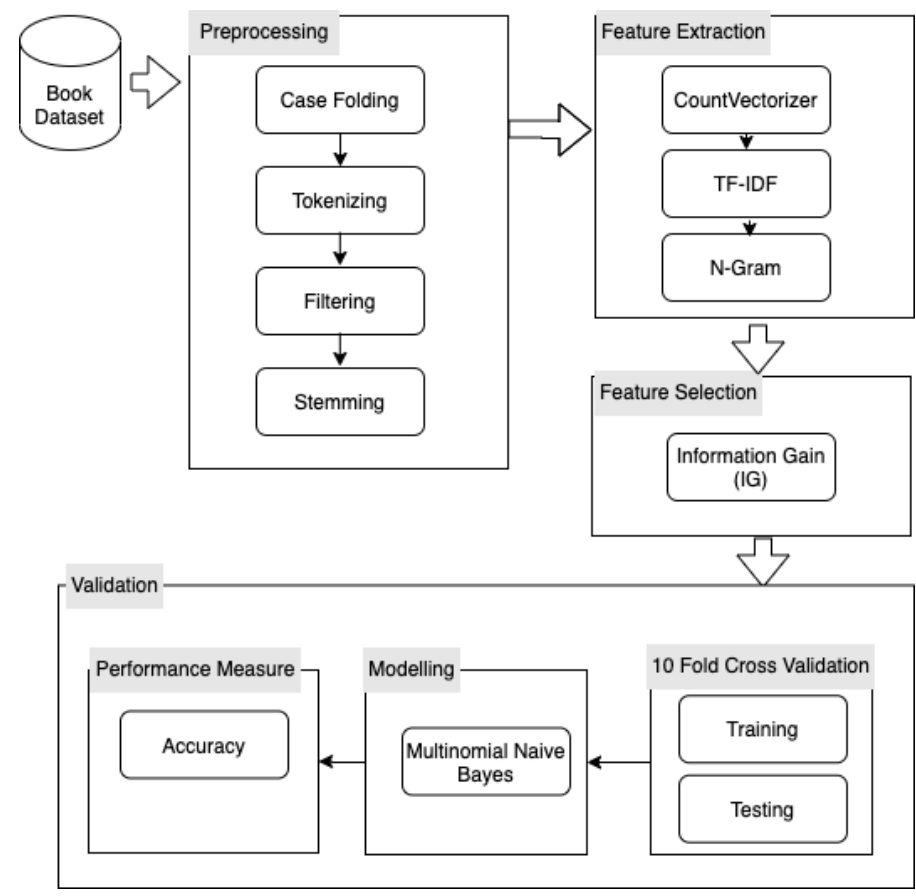




\section{Gambar 1. Metode Penelitian}

Pada Gambar 1 ditunjukkan bahwa kerangka metode yang diusulkan dalam penelitian ini terdiri dari 5 tahap, yaitu:

1. Preprocessing

Pada tahap ini dilakukan proses pengubahan bentuk data yang belum terstruktur menjadi data yang terstruktur sesuai dengan kebutuhan, untuk proses mining yang lebih lanjut. Berikut adalah tahapan metode yang dilakukan dalam preprocessing: case folding, tokenizing, filtering, dan stemming.

2. Feature Extraction

Pada tahap ini dilakukan ekstrasi pada judul buku yang telah dilakukan preprocessing. Ekstraksi fitur dilakukan dengan menerapkan 3 metode yaitu CountVectorizer, TF-IDF dan N-Gram.

3. Feature Selection

Pada tahap ini dilakukan pemilihan fitur (kata) penting dan relevan terhadap data dan mengurangi fitur (kata) yang tidak relevan. Seleksi fitur yang digunakan pada penelitian ini yaitu Information Gain (IG). IG menggunakan teknik scoring untuk pembobotan sebuah fitur dengan menggunakan maksimal entropy. Fitur yang dipilih adalah fitur dengan nilai Information Gain yang lebih besar atau sama dengan nilai threshold tertentu.

4. Modelling

Pada tahap ini dilakukan klasifikasi pada judul buku dengan menggunakan algoritma Multinomial Nä̈ve Bayes.

5. Validation

Pada tahap ini dilakukan pengujian untuk mengetahui pengaruh N-Gram terhadap klasifikasi buku menggunakan ekstraksi fitur, seleksi fitur pada algoritma Multinomial Nä̈ve Bayes.

\subsection{Multinomial Naïve Bayes}

Model multinomial dirancang untuk menentukan frekuensi istilah, yaitu berapa kali istilah tersebut muncul dalam dokumen [5]. Mengingat fakta bahwa suatu istilah mungkin sangat penting dalam menentukan sentimen dokumen, sifat model ini menjadikannya pilihan yang layak untuk klasifikasi dokumen. Selain itu, frekuensi istilah juga membantu dalam memutuskan apakah istilah tersebut berguna atau tidak dalam analisis kami [11]. Kadang-kadang, sebuah istilah dapat hadir dalam dokumen berkali-kali yang meningkatkan frekuensi istilah dalam model ini tetapi pada saat yang sama, itu juga bisa menjadi kata kunci yang berpotensi tidak berarti dalam dokumen tetapi memiliki frekuensi istilah yang tinggi, jadi kata -kata tersebut harus dihapus terlebih dahulu untuk mendapatkan akurasi yang lebih baik dari algoritma ini.

Kelas dokumen di Multinomial Nä̈ve Bayes tidak hanya ditentukan oleh kata-kata yang muncul tetapi juga jumlah kemunculannya:

$$
\begin{aligned}
C_{M A P}=\begin{array}{r}
\arg \max P(c \mid d) \\
c \in\left\{c_{l}, c_{s}\right\}
\end{array} \\
\quad=\underset{c \in\left\{c_{l}, c_{s}\right\}}{\arg \max P(c)} \prod_{k=1}^{m} P\left(t_{k} \mid c\right)
\end{aligned}
$$

\subsection{Information Gain}

Tujuan IG adalah untuk proses pemilihan subset dari feature yang relevan (kata) [12] untuk digunakan dalam pembuatan model klasifikasi buku. Penggunaan metode ini dapat mereduksi dimensi feature dengan cara mengukur reduksi Entropy sebelum dan sesudah pemisahan. IG dikenal juga dengan sebutan Mutual Information (MI) dalam kasus untuk mengetahui dependency antara dua variable $(\mathrm{x}, \mathrm{y})$. IG dapat dirumuskan sebagai berikut:

$$
I G(c, t)=S(c)+\sum_{j \in \text { value }(t)}^{n} \frac{\left|c_{j}\right|}{|c|} S\left(c_{j}\right)
$$

\footnotetext{
Di mana:

$S(c) \quad$ : Entropy seluruh feature $c$ (sebelum pemisahan),

$\mathrm{S}\left(c_{j}\right) \quad:$ Entropy feature $c$ untuk class $t=j$ (setelah pemisahan)

value $(t)$ : himpunan nilai-nilai yang mungkin untuk class $t$,

$n \quad$ : jumlah nilai-nilai yang mungkin untuk class $t$,

$\left|c_{j}\right| \quad$ : jumlah sample class dengan nilai $=j$,

$|c| \quad$ : jumlah sample untuk seluruh class.
}

\subsection{TF-IDF Vectorizer}


Count Vectorizer, berfungsi untuk menghitung frekuensi kata dalam dokumen. Count Vectorizer dapat mengubah fitur teks menjadi sebuah representasi vector [13]. TF-IDF Vectorizer (Term Frequency-Inverse Document Frequency) sama dengan Count Vectorize ditambah dengan TF-IDF [14]. Dengan menggunakan Tfidf Vectorizer, kita dapat dengan mudah membuat daftar file kata-kata yang berpengaruh untuk setiap kelas (kategori).

\subsection{N-Gram}

$\mathrm{N}$-Gram mendefinisikan kombinasi kata-kata tetangga atau panjang huruf $\mathrm{n}$ dalam teks tertentu. Sebuah N-Gram mewakili kelompok kata atau karakter n (ditunjukkan sebagai gram menunjukkan tata bahasa) yang mengikuti satu sama lain. N-Gram dapat digunakan untuk memprediksi kata berikutnya berdasarkan N -1 kata sebelumnya [15]. N-gram banyak digunakan dalam penambangan data dan tugas pengolah kata. Misalnya Jika "Saya bekerja di Kantor" berarti $n=4$ (jumlah kata dari kalimat). Kata tersebut digunakan untuk membuat indeks tentang seberapa sering kata-kata mengikuti satu sama lain. N-gram dapat direpresentasikan dalam formula berikut:

$$
\operatorname{Ngrams}_{k}=X-(N-1)
$$

\section{HASIL DAN PEMBAHASAN}

\subsection{Preprocessing}

Dataset yang digunakan pada penelitian ini yaitu dataset buku yang diperoleh dari dua perpustakaan yaitu Perpustakan Politeknik Negeri Indramayu dan Perpustakaan Daerah Kabupaten Indramayu. Eksperimen dilakukan dengan menggunakan dataset buku yang terdiri dari 514 judul buku berbahasa Inggris. Dataset yang digunakan berformat XLS dengan contoh data buku pada Tabel 1.

Tabel 1. Sample Dataset Buku

\begin{tabular}{lc}
\hline \multicolumn{1}{c}{ Judul } & Klasifikasi \\
\hline Red Hat Linux Networking and System Adiministration Third Edition & 000 \\
Voice \& Data Communications Handbook Fifth Edition & 000 \\
Human-Computer Interaction Third Edition & 000 \\
The Art of Multiprocessor Programming & 000 \\
Computer Networks a Systems Approach & 000 \\
Intel Microprocessors : Architecture & 000 \\
Handbook of Wireless Local Area Networks & 000 \\
Building The Mobile Internet & 000 \\
The 8051 Microcontroller & 000 \\
Synchronization Algorithms and Concurent Programming & 000 \\
CCIE Proffesional Development Routing TCP/IP Volume I second Edition & 000 \\
It Manager's Handbook Second Edition : Getting Your New Job Done & 000 \\
High Performance TCP/IP Networking : concepts Issues and Solutions & 000 \\
Data and Computer Communications Eighth Edition & 000 \\
Core J2EE Patterns Best Practices and design Strategies Second Edition & 000 \\
Cisco Network Design Solutions for Small-Medium Businesses & 000 \\
Body Sensor Networks & 000 \\
Computer Networks Fourth Edition & 000 \\
\hline
\end{tabular}

Pada dataset buku yang digunakan terdapat 2 (dua) atribut yaitu judul dan klasifikasi. Metode pelabelan buku yang digunakan pada penelitian ini yaitu Dewey Decimal Classification (DDC). DDC merupakan metode yang paling banyak digunakan di dunia untuk menentukan kategori buku (labelling) pada perpustakaan. Adapun versi DDC yang digunakan yaitu DDC 23 dengan 10 (sepuluh) kelas utama seperti pada Tabel 2.

Tabel 2. Kelas Utama DDC

\begin{tabular}{cl}
\hline Klasifikasi & \multicolumn{1}{c}{ Kategori Utama } \\
\hline 000 & Computer science, information \& general works \\
100 & Philosophy \& psychology \\
200 & Religion \\
300 & Social sciences \\
400 & Language \\
500 & Pure Science \\
600 & Technology \\
700 & Arts \& recreation \\
\hline
\end{tabular}




\begin{tabular}{cl}
\hline Klasifikasi & \multicolumn{1}{c}{ Kategori Utama } \\
\hline 800 & Literature \\
900 & History \& geography \\
\hline
\end{tabular}

\subsection{Preprocessing}

Pada tahap preprocessing dilakukan pengindeksan untuk memperoleh istilah-istilah yang dianggab mewakili isi dari judul buku. Pengindeksan dapat dilakukan baik secara manual maupun secara otomatis. Pada penelitian ini digunakan pengindeksan secara otomatis menggunakan Natural Language Tool Kit (NLTK) Library. NLTK adalah library Python yang banyak digunakan untuk pemrosesan data dalam bahasa manusia. Ketepatan pemilihan kata pada judul buku menentukan kinerja dari sistem yang dihasilkan.

Pada tahap pengindeksan terdapat beberapa langkah yaitu konversi teks menjadi bentuk standar (case folding), kemudian proses pemecahan kata (tokenisasi), dan filtering (stopword removal) untuk mengambil kembali kata-kata penting yang dihasilkan dari proses sebelumnya. Terakhir, proses stemming untuk menghilangkan sufiks dan prefiks pada setiap kata, sehingga kata yang memiliki sufiks atau prefiks akan kembali ke bentuk dasarnya[16].

\subsubsection{Case Folding}

Teknik case folding digunakan untuk mengubah teks menjadi bentuk standar seperti pada Tabel 3. Terdapat beberapa cara yang dapat digunakan dalam tahap case folding, diantaranya:

a) Mengubah teks menjadi lowercase

Lowercasing adalah proses untuk mengubah semua huruf menjadi huruf non-capital agar menjadi caseinsensitive pada saat dilakukan pemrosesan judul buku.

b) Menghapus angka, tanda baca dan whitespace (karakter kosong)

Keberadaan angka, tanda baca dan whitespace pada judul tidak relevan dengan klasifikasi buku sehingga dilakukan proses penghapusan.

Tabel 3. Penerapan Case Folding

\section{Judul Buku}

Computer Networks a Systems Approach

The 8051 Microcontroller

Intel Microprocessors : Architecture

Building The Mobile Internet

Syncronization Algorithm and Concurent Program

\section{Hasil Case Folding}

computer networks a systems approach

the microcontroller

intel microprocessor architecture

building the mobile internet

syncronization algorithm and concurent program

\subsubsection{Tokenization}

Tokenisasi adalah suatu tahap pemrosesan teks yang dibagi menjadi unit-unit kecil yang disebut token atau term, yang dapat berupa suatu kata atau angka. Token yang dimaksud dalam penelitian ini adalah kata atau term. Proses tokenisasi dilakukan sesuai dengan aturan berikut:

a) Teks dipotong menjadi token

b) Token yang terdisi atas karakter numerik saja, tidak diikutsertakan.

Hasil tokenization pada penelitian ini dapat dilihat pada Tabel 4

Tabel 4. Penerapan Tokenization.

\begin{tabular}{ll}
\hline \multicolumn{1}{c}{ Hasil Case Folding } & \multicolumn{1}{c}{ Hasil Tokenization } \\
\hline computer networks a systems approach & computer, networks, a, systems, approach \\
the microcontroller & the, microcontroller \\
intel microprocessor architecture & intel, microprocessor, architecture \\
building the mobile internet & building, the, mobile, internet \\
syncronization algorithm and concurent program & synchronization, algorithm, and, concurrent, program, \\
\hline
\end{tabular}

\subsubsection{Filtering (Stopword Removal)}

Stopwords merupakan daftar kata-kata yang dianggap tidak memiliki makna. Kata yang tercantum dalam daftar ini dibuang dan tidak ikut diproses pada tahap selanjutnya. Kata-kata yang termasuk dalam stopwords pada umumnya merupakan kata-kata yang sering muncul di setiap dokumen sehingga kata tersebut tidak dapat digunakan sebagai penciri suatu dokumen. Daftar stopwords pada penelitian ini dapat dilihat pada Tabel 5.

Tabel 5. Daftar Stopwords.

\begin{tabular}{llllllll}
\hline a & but & get & http & myself & she'd & they'll & when's \\
about & by & had & i & no & she'll & they're & where \\
above & can & hadn't & i'd & nor & she's & they've & where's \\
after & can't & has & i'll & not & should & this & which \\
\hline
\end{tabular}


JURNAL MEDIA INFORMATIKA BUDIDARMA

Volume 5, Nomor 1, Januari 2021, Page 264-272

ISSN 2614-5278 (media cetak), ISSN 2548-8368 (media online)

Available Online at https://ejurnal.stmik-budidarma.ac.id/index.php/mib DOI 10.30865/mib.v5i1.2672

\begin{tabular}{llllllll}
\hline again & cannot & hasn't & i'm & of & shouldn't & those & while \\
against & com & have & i've & off & since & through & who \\
all & could & haven't & if & on & so & to & who's \\
also & couldn't & having & in & once & some & too & whom \\
am & did & he & into & only & such & under & why \\
an & didn't & he'd & is & or & than & until & why's \\
and & do & he'll & isn't & other & that & up & with \\
any & does & he's & it & otherwise & that's & very & won't \\
are & doesn't & hence & it's & ought & the & was & would \\
aren't & doing & her & its & our & their & wasn't & wouldn't \\
as & don't & here & itself & ours & theirs & we & www \\
at & down & here's & just & ourselves & them & we'd & you \\
be & during & hers & k & out & themselves & we'll & you'd \\
because & each & herself & let's & over & then & we're & you'll \\
been & else & him & like & own & there & we've & you're \\
before & ever & himself & me & r & there's & were & you've \\
being & few & his & more & same & therefore & weren't & your \\
below & for & how & most & shall & these & what & yours \\
between & from & how's & mustn't & shan't & they & what's & yourself \\
both & further & however & my & she & they'd & when & yourselves \\
\hline
\end{tabular}

\subsubsection{Stemming}

Stemming adalah proses menghilangkan infleksi kata ke bentuk dasarnya, namun bentuk dasar tersebut tidak berarti sama dengan akar kata (root word). Misalnya kata "mendengarkan", "dengarkan", "didengarkan" akan ditransformasi menjadi kata "dengar". Dalam hal efisiensi stemming bertujuan untuk mengurangi jumlah kata-kata unik dalam indeks sehingga mengurangi kebutuhan ruang penyimpanan untuk indeks dan mempercepat proses pencarian. Hasil stemming dapat dilihat pada Gambar 2.

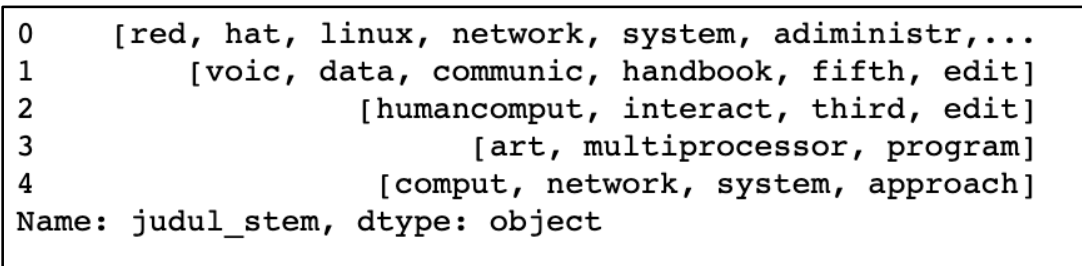

Gambar 2. Hasil Stemming

\subsection{Feature Extraction}

Pada tahap ini dilakukan ekstraksi fitur pada judul buku yang telah melewati tahap preprocessing. Ekstraksi fitur dilakukan dengan menerapkan 2 metode yaitu TF-IDF Vectorizer dan N-Gram.

\subsubsection{TF-IDF Vectorizer}

Teknik CountVectorizer digunakan untuk menghitung frekuensi kata dalam judul buku. CountVectorizer dapat mengubah fitur teks menjadi representasi vektor. Sedangkan TF-IDF atau pembobotan kata merupakan skema yang digunakan untuk menghitung bobot setiap kata yang paling umum digunakan. TF-IDF Vectorizer (Term Frequency-Inverse Document Frequency) merupakan penggabungan CountVectorizer dengan TF-IDF [14]. Dengan menggunakan Tfidf Vectorizer, kita dapat dengan mudah membuat daftar file kata-kata yang berpengaruh untuk setiap kelas (kategori). Di dalam python terdapat library khusus untuk Tfidf Vectorizer sehingga memudahkan untuk pemrosesan ekstraksi fitur. Hasil pemrosesan Tfidf Vectorizer dapat dilihat pada Tabel 6.

Tabel 6. Hasil TF-IDF Vectorizer.

\begin{tabular}{lcccl}
\hline TF & IDF & TF-IDF & Term & \\
\hline array position 53 & 0.125000 & 7.246107 & 0.905763 & adiministration \\
array position 298 & 0.125000 & 2.053150 & 0.256644 & edition \\
array position 418 & 0.125000 & 6.552960 & 0.819120 & hat \\
array position 522 & 0.125000 & 6.147494 & 0.768437 & linux \\
array position 615 & 0.125000 & 5.636669 & 0.704584 & networking \\
array position 751 & 0.125000 & 6.552960 & 0.819120 & red \\
array position 870 & 0.125000 & 4.538057 & 0.567257 & system \\
array position 902 & 0.125000 & 4.027231 & 0.503404 & third \\
\hline
\end{tabular}


JURNAL MEDIA INFORMATIKA BUDIDARMA

Volume 5, Nomor 1, Januari 2021, Page 264-272

ISSN 2614-5278 (media cetak), ISSN 2548-8368 (media online)

Available Online at https://ejurnal.stmik-budidarma.ac.id/index.php/mib DOI 10.30865/mib.v5i1.2672

\subsubsection{N-Gram}

Pada tahap ini dilakukan teknik N-Gram yang menangkap representasi bahasa dari huruf atau kata yang diberikan dalam struktur masukan (judul). Pada penelitian ini digunakan 3 (tiga) Teknik N-Gram yaitu Unigram $(\mathrm{n}=1$ ), Bigram ( $n=2)$, dan Trigram ( $n=3)$. Pertama, fitur unigram dihasilkan dari data dan diuji masing-masing dengan pembobotan tf, pembobotan tf-idf \& Tfidf Vectorizer. Selanjutnya digunakan fitur bigram dan trigram dengan proses pembobotan yang sama.

\subsection{Feature Selection}

Setealah tahap N-Gram dilakukan, tahap selanjutnya yaitu pemilihan fitur untuk Unigram, Bigram, dan Trigram. Pada tahap ini, fitur (kata) penting dan relevan dipilih serta fitur yang tidak relevan (kata) dikurangi. Metode Information Gain (IG) digunakan dalam penelitian ini untuk pemilihan fitur. IG menggunakan teknik penilaian untuk membobot fitur menggunakan entropi maksimum. Fitur yang dipilih adalah fitur dengan nilai IG yang lebih besar atau sama dengan nilai ambang batas tertentu. IG dikenal juga dengan sebutan Mutual Information (MI).

Pada penelitian ini digunakan modul feature selection mutual_info_classif() yang merupakan library dari scikit-learn python. Selanjutnya dilakukan penerapan Sparse Matrix TF-IDF dengan penentuan nilai threshold MI sebesar 0.01 . Sehingga fitur yang akan dipilih hanya fitur yang memiliki nilai MI $\geq 0.01$. Hasil MI untuk nilai term (kata) dengan nilai TF-IDF dapat dilihat pada Tabel 5 s.d 7.

Tabel 7. Hasil MI_Unigram.

\begin{tabular}{lrrr}
\hline & term & rank & MI_unigram \\
\hline $\mathbf{2 9 8}$ & edition & 65.480965 & 0.044117 \\
$\mathbf{4 1 5}$ & handbook & 41.739993 & 0.082091 \\
$\mathbf{3 2 3}$ & engineering & 34.860862 & 0.124951 \\
$\mathbf{7 9 1}$ & second & 28.959493 & 0.368981 \\
$\mathbf{3 8 8}$ & fundamentals & 27.573493 & 0.049067 \\
$\mathbf{6 3 0}$ & nursing & 26.390277 & 0.709766 \\
$\mathbf{2 6 1}$ & design & 25.758784 & 0.000000 \\
$\mathbf{8 7 1}$ & systems & 25.714765 & 0.102712 \\
$\mathbf{5 6 5}$ & mechanics & 22.652411 & 0.151356 \\
$\mathbf{7 5 5}$ & refrigeration & 17.147243 & 0.473521 \\
\hline
\end{tabular}

Pada tabel 5 dapat dilihat 10 peringkat tertinggi hasil TF-IDF pada unigram.

Tabel 8. Hasil MI_Bigram.

\begin{tabular}{rrrr}
\hline & \multicolumn{1}{l}{ term } & rank & MI_bigram \\
\hline $\mathbf{1 3 4 7}$ & second edition & 34.806776 & 0.139504 \\
$\mathbf{5 9 7}$ & fluid mechanics & 23.934719 & 0.293987 \\
$\mathbf{1 5 3 9}$ & third edition & 19.108572 & 0.000000 \\
$\mathbf{6 1 1}$ & fourth edition & 19.046829 & 0.000000 \\
$\mathbf{1 3 8 3}$ & sixth edition & 17.340208 & 0.226224 \\
$\mathbf{6 6}$ & air conditioning & 17.093346 & 0.182321 \\
$\mathbf{5 8 7}$ & fifth edition & 14.082482 & 0.000000 \\
\hline
\end{tabular}


JURNAL MEDIA INFORMATIKA BUDIDARMA

Volume 5, Nomor 1, Januari 2021, Page 264-272

ISSN 2614-5278 (media cetak), ISSN 2548-8368 (media online)

Available Online at https://ejurnal.stmik-budidarma.ac.id/index.php/mib

DOI 10.30865/mib.v5i1.2672

\begin{tabular}{rrrr}
\hline & term & rank & MI_bigram \\
\hline $\mathbf{6 3 7}$ & fundamentals turbomachinery & 13.105919 & 0.000000 \\
$\mathbf{7 1 6}$ & handbook volume & 10.787271 & 0.444005 \\
$\mathbf{1 2 8}$ & asm handbook & 10.787271 & 0.450510 \\
\hline
\end{tabular}

Pada tabel 8. dapat dilihat 10 peringkat tertinggi hasil TF-IDF pada bigram.

Tabel 9. Hasil IG_Trigram.

\begin{tabular}{rlll}
\hline $\mathbf{1 0 8}$ & term & rank & IG_trigram \\
\hline $\mathbf{1 1 7 4}$ & refrigeration air conditioning & 13.701 .969 & 0.000000 \\
$\mathbf{4 2 0}$ & electrical engineering handbook & 10.758 .115 & 0.000000 \\
$\mathbf{4 1 7}$ & electric motor handbook & 10.066 .796 & 0.000000 \\
$\mathbf{5 1}$ & air conditioning refrigeration & 9.829 .439 & 0.000000 \\
$\mathbf{4 4 5}$ & encyclopedia optical engineering & 9.726 .919 & 0.140841 \\
$\mathbf{1 0 1 1}$ & optical engineering volume & 9.221 .242 & 0.164270 \\
$\mathbf{8 9 2}$ & mechanics sixth edition & 9.221 .242 & 0.000000 \\
$\mathbf{5 4 7}$ & fluid mechanics sixth & 8.196 .659 & 0.000000 \\
$\mathbf{5 6 4}$ & fundamentals engineering thermodynamics & 8.196 .659 & 0.483265 \\
& 7.863 .552 & 0.000000 \\
\hline
\end{tabular}

Pada tabel 9 dapat dilihat 10 peringkat tertinggi hasil TF-IDF pada trigram.

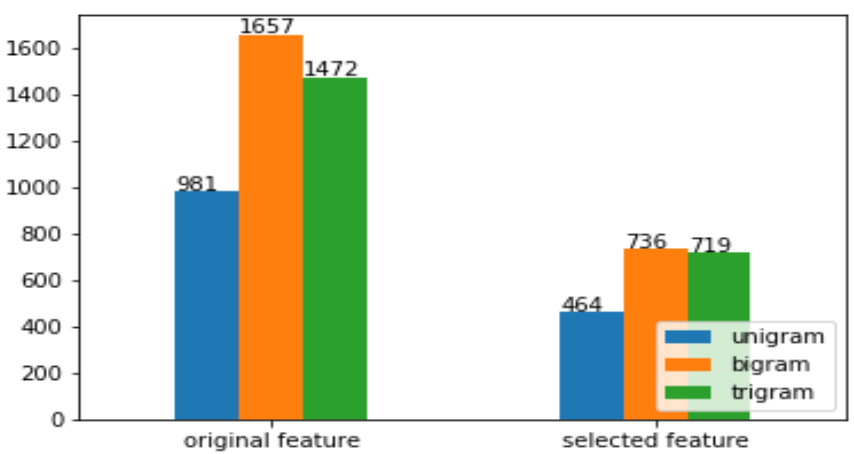

Gambar 3. Hasil Seleksi Fitur pada Unigram, Bigram dan Trigram

Gambar 3. Menunujukan chart sparse matrix hasil seleksi fitur dari unigram, bigram dan trigram. Hanya fitur yang telah terpilih (relevan) yang akan digunakan pada tahap modelling dan evaluasi.

\subsection{Modelling and Validation}

Tahap terakhir dilakukan verifikasi terhadap pengaruh seleksi fitur terhadap kinerja metode Multinomial Nä̈ve Bayes (MNB) pada proses klasifikasi buku perpustakaan. Kami menguji menggunakan validasi silang 10 kali lipat pada algoritma Multinomial Naïve Bayes.

Pengujian pertama dilakukan pada metode MNB tanpa seleksi fitur yang kemudian didapat hasil nilai akurasi sebesar $67,8 \%$. Pengujian kedua dilakukan pada metode MNB dengan penerapan seleksi fitur pada NGram. Hasil akurasi klasifikasi menunjukan Unigram memiliki akurasi tertinggi sebesar 74,4\%, seperti pada Tabel 8 .

Tabel 8. Perbandingan Nilai Akurasi MNB + N-Gram.

\begin{tabular}{ccc}
\hline Unigram & Bigram & Trigram \\
\hline $74,4 \%$ & $54,9 \%$ & $38,6 \%$ \\
\hline
\end{tabular}

\section{KESIMPULAN}

Dari hasil penerapan ekstraksi dan seleksi fitur pada model klasifikasi Multinomial Nä̈ve Bayes, maka dapat diambil kesimpulan bahwa penerapan ekstraksi fitur TF-IDF, N-Gram yang di integrasikan dengan seleksi fitur Information Gain (IG) memiliki pengaruh yang signifikan terhadap performansi algoritma klasifikasi Multinomial Nä̈ve Bayes dalam proses pelabelan buku. Dengan peningkatan nilai akurasi sebesar $6,6 \%$. Pemilihan fitur dengan 


\section{JURNAL MEDIA INFORMATIKA BUDIDARMA}

Volume 5, Nomor 1, Januari 2021, Page 264-272

ISSN 2614-5278 (media cetak), ISSN 2548-8368 (media online)

Available Online at https://ejurnal.stmik-budidarma.ac.id/index.php/mib DOI 10.30865/mib.v5i1.2672

Unigram, Bigram, Trigram menghasilkan nilai akurasi tertinggi oleh Unigram sebesar 74,4\% lebih baik dibandingkan nilai akurasi Bigram dan Trigram.

\section{REFERENCES}

[1] A. Ibrahim, "Pengantar Ilmu Perpustakaan dan Arsiparis.” Gunadarma Ilmu, Jakarta Pusat, 2017.

[2] J. Watthananon, "The relationship of text categorization using Dewey Decimal Classification techniques," Int. Conf. ICT Knowl. Eng., vol. 2015-Janua, no. January, pp. 72-77, 2015

[3] K. D. K. W. Aisya Frisilya, Wawan Yunanto, "Klasifikasi Kompetensi Tugas Akhir Secara Otomatis Berdasarkan Deskripsi Singkat Menggunakan Per- bandingan Algoritma K-NN dan Naive Bayes.” Jurnal Aksara Komputer Terapan, 2016.

[4] E. Setiani and W. Ce, "Text Classification Services Using Naïve Bayes for Bahasa Indonesia," Proc. 2018 Int. Conf. Inf. Manag. Technol. ICIMTech 2018, no. September, pp. 361-366, 2018.

[5] G. Singh, B. Kumar, L. Gaur, and A. Tyagi, "Comparison between Multinomial and Bernoulli Naïve Bayes for Text Classification,” 2019 Int. Conf. Autom. Comput. Technol. Manag. ICACTM 2019, pp. 593-596, 2019.

[6] R. S. Ramya, K. R. Venugopal, S. S. Iyengar, and L. M. Patnaik, "Feature extraction and duplicate detection for text mining: A survey," Glob. J. Comput. Sci. Technol. C Softw. Data Eng., vol. 16, no. 5, pp. 1-20, 2016.

[7] A. I. Kadhim, "Term Weighting for Feature Extraction on Twitter: A Comparison between BM25 and TF-IDF," 2019 Int. Conf. Adv. Sci. Eng. ICOASE 2019, pp. 124-128, 2019.

[8] L. Zhu, G. Wang, and X. Zou, "Improved information gain feature selection method for Chinese text classification based on word embedding," ACM Int. Conf. Proceeding Ser., pp. 72-76, 2017.

[9] S. S. Kumar and A. Rajini, "An Efficent Sentimental Analysis for Twitter Using Neural Network based on Rmsprop," IOSR J. Eng., no. Iccids, pp. 17-25, 2018.

[10] X. Zhang and B. Wu, "Short Text Classification based on feature extension using the N-Gram model," 2015 12th Int Conf. Fuzzy Syst. Knowl. Discov. FSKD 2015, pp. 710-716, 2016.

[11] M. Abbas, K. Ali Memon, and A. Aleem Jamali, "Multinomial Naive Bayes Classification Model for Sentiment Analysis," IJCSNS Int. J. Comput. Sci. Netw. Secur., vol. 19, no. 3, p. 62, 2019.

[12] C. Yin and J. Xi, "Maximum entropy model for mobile text classification in cloud computing using improved information gain algorithm," Multimed. Tools Appl., vol. 76, no. 16, pp. 16875-16891, 2017.

[13] Munawar, "Sistem Pendeteksi Berita Palsu (Fake News) di Media Sosial dengan Teknik Data Mining Scikit Learn," Perpust. Univ. Esa Unggul, 2019.

[14] U. Suleymanov, B. K. Kalejahi, E. Amrahov, and R. Badirkhanli, "Text Classification for Azerbaijani Language Using Machine Learning and Embedding," 2018.

[15] A. K. Pandey and N. K. Goyal, "Fault Prediction Model by Fuzzy Profile Development of Reliability Relevant Software Metrics," vol. 11, no. 6, pp. 34-41, 2010.

[16] S. Kannan et al., "Preprocessing Techniques for Text Mining," Int. J. Comput. Sci. Commun. Networks, vol. 5, no. 1, pp. 7-16, 2015. 